\title{
Attempt to quantitate relation between cardiac function and infarct size in acute myocardial infarction ${ }^{1}$
}

\author{
D. Mathey, W. Bleifeld, P. Hanrath, and S. Effert \\ From the Department of Internal Medicine I, the Rheinisch-Westfälische Technische Hochschule, Aachen, \\ Germany
}

In 82 patients with acute myocardial infarction, observed haemodynamic changes were compared with the average maximal serum enzyme rise and the infarct size, as calculated from serial determinations of creatine phosphokinase concentration. For this purpose, patients were divided into 3 groups according to their pulmonary artery end-diastolic pressure at the time of admission. There were 19 patients in group I with pulmonary artery end-diastolic pressure $<I 2 \mathrm{mmHg}$; they had an average infarction size of $17 \mathrm{~g}$ and no impairment of cardiac function. In the 35 patients in group II with pulmonary artery end-diastolic pressure I2 to $20 \mathrm{mmHg}$, the pressure was raised to a mean value of $15.4 \pm 0.4 \mathrm{mmHg}$ with a slight decrease of cardiac index $\left(2 \cdot 5 \pm 0.1 \mathrm{l}\right.$. $/ \mathrm{min}$ per $\left.\mathrm{m}^{2}\right)$ and left ventricular stroke work index $\left(5 \mathrm{I} \cdot 4 \pm 4.7 \mathrm{~g} \mathrm{~m} / \mathrm{m}^{2}\right)$. Loss of myocardium in group II was $42 \mathrm{~g}$ and mortality was $2 \mathrm{I}$ per cent. There were 28 patients in group III with pulmonary artery end-diastolic pressure $>20 \mathrm{mmHg}$, who had an average infarct size of $99 \mathrm{~g}$. Cardiac index $\left(I .9 \pm 0.2 \mathrm{l} . / \mathrm{min} / \mathrm{m}^{2}\right)$, and stroke work index $\left(27.5 \pm 5.7 \mathrm{~g} \mathrm{~m} / \mathrm{m}^{2}\right)$ declined significantly $(P<0.00 \mathrm{r})$. Mean end-diastolic pressure rose to $28 \cdot 3 \pm I \cdot I \mathrm{mmHg}$. Mortality in group $I I I(60 \%)$ was mainly due to cardiogenic shock.

It is concluded that the decrease of cardiac function in the acute phase of myocardial infarction must usually be ascribed to the amount of recent myocardial necrosis. Stiffening of the infarct area and normal or increased contractility of the non-infarcted myocardium are regarded as compensatory mechanisms. The - combined investigation of haemodynamic and serial enzyme changes is considered to be an appropriate method for the separation of old from recent myocardial necrosis and for providing information predictive of the immediate and the long-term prognosis.

At present heart failure is the most serious complication of acute myocardial infarction in coronary care units (Bleifeld et al., I972; Rutherford, McCann, and O'Donovan, I97I). There are probably several mechanisms by which acute myocardial infarction causes left heart failure. One is obviously the loss of left ventricular myocardium by previous or acute infarcts (Page et al., 1971; Harnarayan et al., 1970). The amount of acute myocardial necrosis can be estimated by measuring the serum enzyme rise after coronary occlusion. In order to quantitate the relation between the extent of myocardial infarction and the impairment in left ventricular function, serum enzyme changes were correlated with left ventricular haemodynamics.

\footnotetext{
Received 10 September 1973.

1 Support by the Deutsche Forschungsgemeinschaft SFB rog.
}

\section{Patients}

Included in the study were 82 patients with acute transmural myocardial infarction. The diagnosis of acute myocardial infarction was based on the following. I) The relevant history; 2) the typical electrocardiographic criteria (evolution of $Q$ waves, alterations in the ST segments and $T$ waves); and 3 ) serial rises in creatine phosphokinase (CPK), aspartate aminotransferase (GOT), lactic dehydrogenase (LDH), and $\alpha$-hydroxybutyrate dehydrogenase ( $\alpha-\mathrm{HBDH})$ in serum.

The patients were considered to be in cardiogenic shock, if I) reduced blood flow was evident from cold, clammy, cyanotic skin, mental obtundation, and from a urine output less than $20 \mathrm{ml} /$ hour; and 2) systolic blood pressure was below $90 \mathrm{mmHg}$ or, in previous hypertensive subjects, $30 \mathrm{mmHg}$ less than their normal values, during a period of at least 30 minutes.

Patients with atrial fibrillation, ectopic tachycardias, 
ventricular fibrillation, and total AV block were excluded from the study.

The patients were split into 3 groups according to left ventricular filling pressure at the time of admission. Though this was measured directly in $4 \mathrm{I}$ patients, pulmonary artery end-diastolic pressure which is obtained more easily and without risk (Bleifeld et al., r973) was used for the classification. This was possible, because in agreement with Kaltman et al. (1966), Hunt et al. (I970) and Scheinmann et al. (1973), 43 simultaneous measurements of left ventricular end-diastolic pressure and pulmonary artery end-diastolic pressure in 22 patients gave an excellent correlation $(\mathrm{r}=0.93)$ between the two pressures. Group I consisted of 19 patients with an enddiastolic pulmonary artery pressure below $12 \mathrm{mmHg}$. In group II $(n=35)$ end-diastolic pulmonary artery pressure ranged between 12 and $20 \mathrm{mmHg}$. End-diastolic pulmonary artery pressure exceeded $20 \mathrm{mmHg}$ in group III $(n=28)$.

\section{Haemodynamic data}

All patients were examined in the coronary care unit, on an average, 6 hours after the beginning of pain, while lying in bed. Under local anaesthesia and without fluoroscopy, catheters were inserted via the medial antecubital vein or the femoral vein and via the femoral artery using the Seldinger technique. Pressures in the right heart and the pulmonary artery were obtained in all patients by means of double- or triple-lumen SwanGanz balloon-catheter ${ }^{1}$ (Swan et al., 1970; Bleifeld, 1973). In $4 \mathrm{I}$ patients $7 \mathrm{~F}$ Oedman catheters ${ }^{2}$ with the lumen at the end and a preshaped bent tip were manipulated via the femoral artery into the central aorta and from there during continuous pressure and electrocardiographic monitoring into the left ventricle. All pressures were recorded with Statham $\mathrm{P}_{23 \mathrm{~dB}^{3}}$ strain gauges mounted at the level of the mid-thorax for the zero position.

Cardiac output determinations were performed by the dye dilution technique using injections of idocyanine green into the pulmonary artery and sampling from the central aorta using a Waters X 350 cuvette densitometer. ${ }^{4}$

Pressures and dye dilution curves were recorded on an 8-channel-printer. ${ }^{5} \mathrm{With}$ the exclusion of a haematoma at the site of arterial puncture in one patient with an unknown bleeding disorder, no serious complications were seen.

\section{Serum enzyme determinations}

Serum samples for CPK, GOT, LDH, and $\alpha-\mathrm{HBDH}$ determinations were obtained at the time of admission, the next morning, and daily in the further course. In some patients, samples were taken every 3 hours for serial determinations of creatine phosphokinase. Enzyme activities were determined kinetically at $25^{\circ} \mathrm{C}$. CPK

1 Edwards Laboratories, Santa Ana, California, U.S.A.

2 KIFA, Stockholm, Sweden.

3 Statham Instruments, Inc., California, U.S.A.

4 Waters Instruments, Inc., Los Angeles, California, 90064, U.S.A.

${ }^{5}$ Oscillomink, Siemens, Erlangen, West Germany.

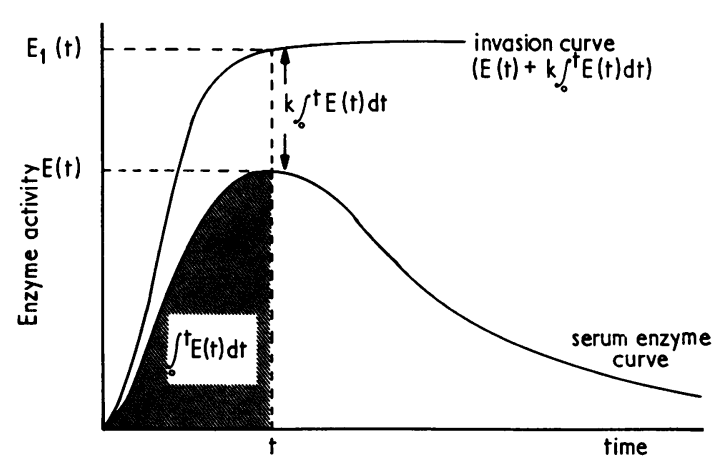

FIG. I The invasion curve represents the enzyme concentration that would appear in the distribution space if the enzyme were not eliminated. The invasion curve can be reconstructed from the serum enzyme curve by adding the product of the rate constant of elimination $k$ with the integral $\int_{0}^{t} E(t) d t$ to the actual enzyme concentration $E(t)$.

activity was measured with Boehringer CPK-activated test sets. ${ }^{1}$ GOT-, LDH-, and $\alpha$-HBDH-activities in the serum were assayed in a suboptimal substrate concentration with Boehringer test sets. ${ }^{1}$ The upper normal values are as follows: CPK $40 \mathrm{mU} / \mathrm{ml}$, GOT $12 \mathrm{mU} / \mathrm{ml}$, $\mathrm{LDH} 200 \mathrm{mU} / \mathrm{ml}$, and $\alpha-\mathrm{HBDH} 140 \mathrm{mU} / \mathrm{ml}$.

\section{Calculations \\ Haemodynamic values}

For the determination of cardiac output from the dye dilution curves the formula of Williams, O'Donovan, and Wood (1966) was used. Left ventricular stroke work index (LVSWI) was determined from the following relation.

$$
\text { LVSWI }=\frac{(\text { MSP-LVEDP }) \cdot S V I \cdot r \cdot 36}{100} \mathrm{~g} \mathrm{~m} / \mathrm{m}^{2}
$$

with $M S P=$ mean systolic pressure; $L V D E P=$ left ventricular end-diastolic pressure; $\mathrm{SVI}=$ stroke volume index.

Diastolic stiffness is defined as the pressure change $\mathrm{dP}$ for a given change in volume $d V$. In this study $d P / d V$ was evaluated from the quotient $\Delta \mathrm{P} / \Delta \mathrm{V}$ as an approximation of $\mathrm{dP} / \mathrm{dV}$ according to Diamond and Forrester (1972).

$$
\frac{\Delta \mathrm{P}}{\Delta \mathrm{V}}=\frac{\text { LVEDP-LVESP }}{\mathrm{SV}} \frac{\mathrm{mmHg}}{\mathrm{ml}}
$$

with $L V E D P=$ left ventricular end-diastolic pressure; LVESP $=$ left ventricular end-systolic pressure; $S V=$ stroke volume.

In all patients a shock index (Bleifeld et al., 1973) appropriate for the early recognition of cardiogenic shock and derived from

$$
\frac{(\text { SAP-PAEDP }) \cdot \mathrm{CI}}{\text { PAEDP } \cdot \text { AVDO }_{2}}
$$

${ }^{1}$ Boehringer Mannheim, Mannheim, West Germany. 
TABLE I Haemodynamic data in each group

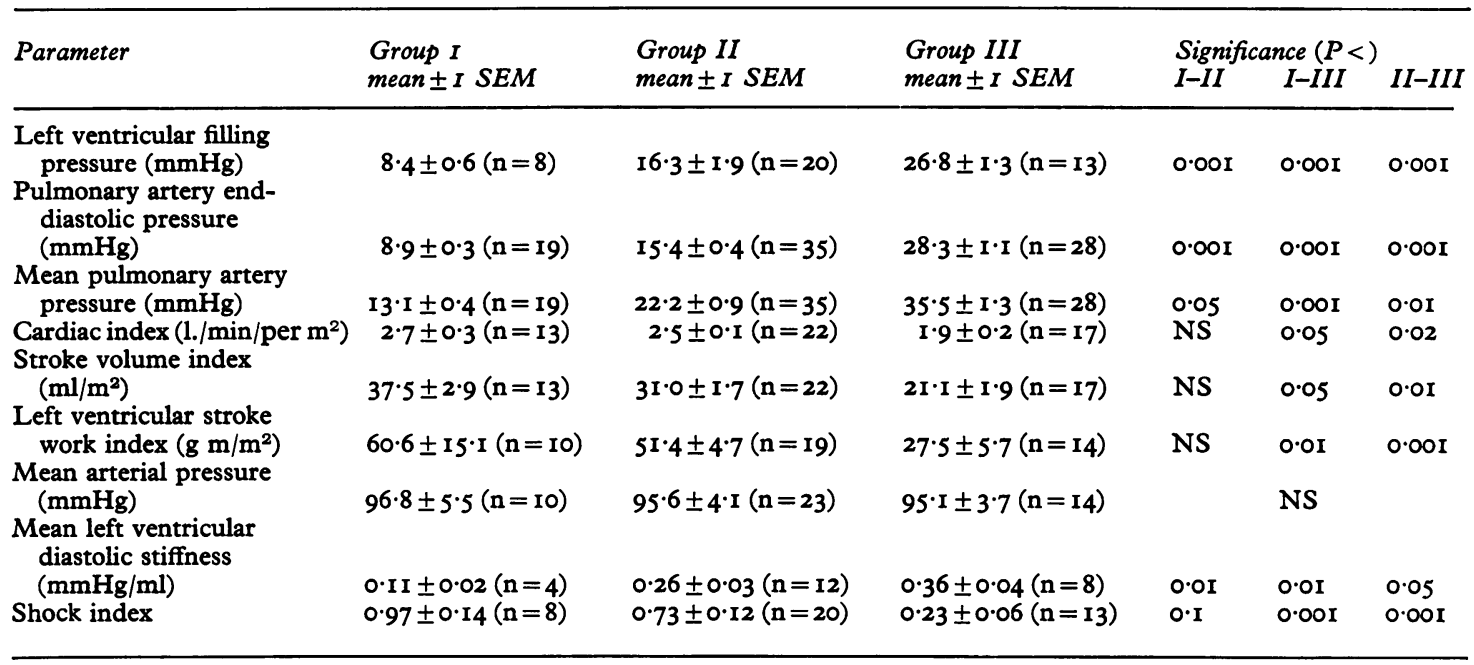

was calculated: $\mathrm{SAP}=$ systolic arterial pressure; $\mathrm{CI}=$ Cardiac output index; $\mathrm{AVDO}_{2}=$ arteriovenous oxygen difference.

Patients with cardiogenic shock had an index below 0.3 .

\section{Determination of infarct size}

As recently described by Sobel et al. (1972), the mass of a myocardial infarct (I) in man can be estimated from serial determinations of creatine phosphokinase concentration using the equation:

$$
\mathrm{I}(\mathrm{g})=\frac{\mathrm{CPK}_{\mathrm{D}}(\mathrm{IU})}{\mathrm{CPK}_{\mathrm{N}}-\mathrm{CPK}_{\mathrm{I}}(\mathrm{IU} / \mathrm{g})}
$$

with $\mathrm{CPK}_{\mathrm{D}}=$ total amount of depleted CPK in the infarct area (IU); $\mathrm{CPK}_{\mathrm{N}}=\mathrm{CPK}$ activity in the normal human myocardium (IU/g); $\mathrm{CPK}_{\mathrm{I}}=\mathrm{CPK}$ activity in the homogenized infarct tissue (IU/g).

$\mathrm{CPK}_{\mathrm{D}}$ is obtained from the amount of CPK released $\left(C P K_{R}\right)$ into the circulation $\left(C P K_{D}=C P K_{R} / 0 \cdot 3\right)$. $\mathrm{CPK}_{\mathrm{R}}$ is obtained by multiplying the volume of the CPK distribution space with the peak value of the amount of CPK that invades one millilitre of the distribution space (according to Sobel et al. (I972) II.4\% of the body weight). The maximal amount of CPK that invades the distribution volume can be evaluated from CPK serial determinations as follows (Fig. I): the actual CPK concentration in serum is the result of two contrary mechanisms, namely invasion from the destructed myocardium and elimination. If the rate constant of elimination $\mathrm{k}$ is known, the invasion curve can be calculated from the CPK serum curve, by addition of the eliminated CPK $E_{e l}(t)$ to the actual concentration of CPK $E(t)$. It is accordingly (Gladtke and Hattingberg, I973)

$$
E_{1}(t)=E(t)+E_{e l}(t)
$$

$E_{e l}(t)$ depends on the rate constant of elimination $k$ and the area limited by the CPK serum curve, i.e. the integral $\int_{0}^{t} E(t)(d t)$. Thus equation ( $I$ ) changes into:

$$
E_{1}(t)=E(t)+k \cdot \int_{0}^{t} E(t) d t
$$

Equation (2) was calculated by using a Fortran programme. CPK values as a function of time were plotted by the computer. The values were approximated by the mathematically best fitting curve. This approximated curve was used for the calculation of equation (2). The values of equation (2) as a function of time, the so-called invasion curve, were plotted by the computer as well.

The rate constant of elimination $k$ was calculated from the CPK serum curve. It proved to be necessary to determine $\mathbf{k}$ for each of the approximated curves and to use the value $k$ thus obtained for the calculation of the invasion curve. In group $\mathrm{I}, \mathrm{k}$ was $0.053 \mathrm{~h}^{-1}$; in group II, $0.054 \mathrm{~h}^{-1}$; and in group III, $0.075 \mathrm{~h}^{-1}$. Further details of the methods used are described elsewhere (Mayiopulos et al., 1974).

\section{Results}

\section{Haemodynamic alterations}

Table I summarizes the haemodynamic results in 82 patients. Excluding mean arterial pressure and heart rate, highly significant differences were observed between the 3 groups.

In group I with pulmonary artery end-diastolic pressure $<$ I2 $\mathrm{mmHg}$ the I9 patients had normal pressures in the pulmonary circulation. The mean pulmonary artery pressures was $13 \cdot 1 \pm 0.4 \mathrm{mmHg}$. Pulmonary artery end-diastolic pressure ranged from 7 to I I mmHg (mean: $8.9 \pm 0.3 \mathrm{mmHg}$ ). Cardiac index and left ventricular stroke work index were not significantly decreased.

There was a slight increase of left ventricular 
TABLE 2 Mean maximal serum values of $C P K, G O T, L D H$, and $\alpha-H B D H$

\begin{tabular}{|c|c|c|c|c|c|c|}
\hline Serum enzyme & $\begin{array}{l}\text { Group I } \\
\text { mean } \pm I S E M\end{array}$ & $\begin{array}{l}\text { Group II } \\
\text { mean } \pm \text { I SEM }\end{array}$ & $\begin{array}{l}\text { Group III } \\
\text { mean } \pm \text { I SEM }\end{array}$ & $\begin{array}{l}\text { Signifi } \\
I-I I\end{array}$ & $\begin{array}{c}\text { ince }(P< \\
I-I I I\end{array}$ & $I I-I I I$ \\
\hline $\begin{array}{l}\text { CPK (mU/ml) } \\
\text { GOT (mU/ml) } \\
\text { LDH (mU/ml) } \\
\alpha-\mathrm{HBDH}(\mathrm{mU} / \mathrm{ml})\end{array}$ & $\begin{array}{c}315 \pm 47 \cdot 4(n=19) \\
69 \cdot 4 \pm 7 \cdot 8(n=19) \\
490 \cdot 3 \pm 33 \cdot 3(n=19) \\
315 \cdot 1 \pm 22 \cdot 5(n=17)\end{array}$ & $\begin{array}{r}443 \cdot 9 \pm 39 \cdot 4(n=34) \\
98 \cdot 3 \pm 10 \cdot 2(n=35) \\
710 \cdot 7 \pm 41 \cdot 5(n=33) \\
543 \cdot 2 \pm 44 \cdot 1(n=29)\end{array}$ & $\begin{array}{l}874 \cdot 7 \pm 125 \cdot 4(n=20) \\
316 \cdot 3 \pm 129 \cdot 2(n=21) \\
867 \cdot 6 \pm 99 \cdot 7(n=21) \\
646 \cdot 4 \pm 78 \cdot 8(n=17)\end{array}$ & $\begin{array}{l}0.05 \\
0.1 \\
0.001 \\
0.001\end{array}$ & $\begin{array}{l}0.001 \\
0.001 \\
0.001 \\
0.001\end{array}$ & $\begin{array}{l}0.01 \\
0.01 \\
\text { NS } \\
\text { NS }\end{array}$ \\
\hline
\end{tabular}

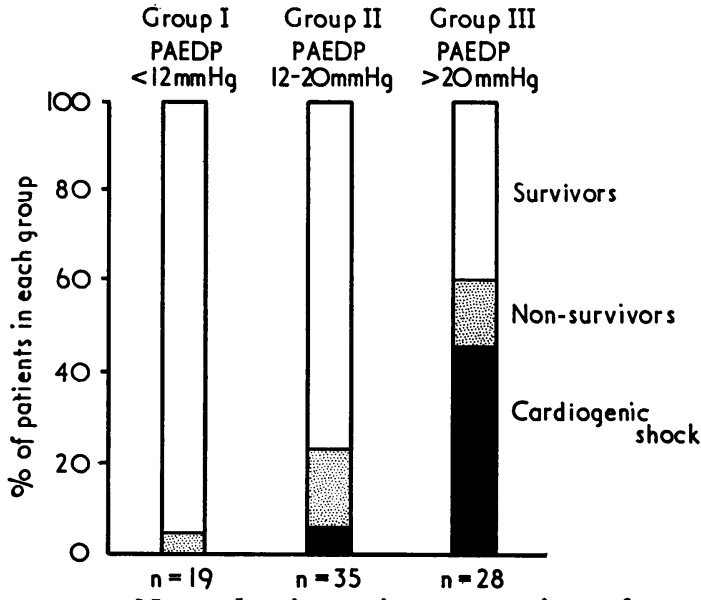

FIG. 2 Note the increasing proportion of nonsurvivors from group I to group III. Fifty per cent of the patients in group III died in cardiogenic shock.

stiffness with $0.1 \mathrm{I} \pm 0.02 \mathrm{mmHg} / \mathrm{ml}$ compared to normal $(0.07 \mathrm{mmHg} / \mathrm{ml})$. According to the slight impairment in left ventricular haemodynamics no clinical signs of left heart failure were observed. Only one patient died on the 5th day from heart rupture.

Group II consisted of 35 patients with moderately increased pressures in the pulmonary artery. The mean pulmonary artery end-diastolic pressure was $15.4 \pm 0.4 \mathrm{mmHg}$, significantly higher $(P<$ $0.001)$ than in group I. Slight but not significant decreases of cardiac index $\left(2.5 \pm 0.11 . / \mathrm{min}\right.$ per $\left.\mathrm{m}^{2}\right)$ and left ventricular stroke work index $(5 \mathrm{I} \cdot 4 \pm 4 \cdot 7 \mathrm{~g}$ $\mathrm{m} / \mathrm{m}^{2}$ ) were observed compared to the patients in group I. Left ventricular stiffness was further increased to $0.26 \pm 0.03 \mathrm{mmHg} / \mathrm{ml}(P<0.01)$. Nineteen patients $(55 \%)$ in group II had pulmonary râles. Mean pulmonary end-diastolic pressure in these patients was $16.6 \mathrm{mmHg} ; 20$ per cent of group II died, two after cardiogenic shock (Fig. 2).

In the 18 patients included in group III with pulmonary artery end-diastolic pressures $>20$ mmHg there was a significant impairment of left ventricular function. The mean pulmonary artery end-diastolic pressure was significantly greater $(28.3 \pm \mathrm{I} \cdot \mathrm{I} \mathrm{mmHg})$ as compared with group I and II $(P<0.001)$, and left ventricular end-diastolic pressure was raised to $26 \cdot 8 \pm \mathrm{I} \cdot 3 \mathrm{mmHg}$. Cardiac index $\left(\mathrm{I} \cdot 9 \pm 0.2 \mathrm{ml} / \mathrm{min} / \mathrm{m}^{2}\right)$ and left ventricular stroke work index $\left(27.5 \pm 5.7 \mathrm{~g} \mathrm{~m} / \mathrm{m}^{2}\right)$ were significantly reduced $(P<0.001)$. The mean shock index was $0.23 \pm 0.6(P<0.001)$, which was below 0.3 , the upper limit of patients with cardiogenic shock previously observed in our department (Bleifeld et al., 1973). In 73 per cent there was clinical evidence of left heart failure. Fifty per cent of these patients died in cardiogenic shock and mortality was very high in 85 per cent of group III (Fig. 2).

\section{Enzymes}

The mean maximal values of the rise of the different enzymes are summarized in Table 2. There were significant differences between the three groups. The peak value of the CPK in group I was 315 $47 \mathrm{mU} / \mathrm{ml}$, significantly less $(P<0.05)$ than in group II with $444 \pm 39 \mathrm{mU} / \mathrm{ml}$. A further increase was observed in group III to $875 \pm 125 \mathrm{mU} / \mathrm{ml}$, which was 22 times the normal $(P<0.001)$. CPK peaked in the mean 24 hours after the first signs of infarction.

The concentration of GOT in the serum was found to rise in group I to $69 \pm 8 \mathrm{mU} / \mathrm{ml}$, and in group II to $98 \pm 10 \mathrm{mU} / \mathrm{ml}$. The peak value of group III was $316 \pm 130 \mathrm{mU} / \mathrm{ml}$, which was 26 times the normal value $(P<0 \cdot 001$ compared to groups I and II). The mean maximal value of GOT was measured 42 hours after the infarction.

Significant differences were also observed between the three groups for LDH and $\alpha-\mathrm{HBDH}$. The constant quotient $\mathrm{LDH} / \alpha-\mathrm{HBDH}$ of $\mathrm{I} \cdot 4$ indicates that the $\mathrm{LDH}$ originated in all three groups from the heart muscle that had been destroyed. In group III both enzymes were raised to 4 times the normal (LDH 867 $\pm 99 \cdot 7, \alpha-\mathrm{HBDH} \quad 646 \pm 79$, P < 0.00 I compared to group I). Maximal values of $\mathrm{LDH}$ and $\alpha-\mathrm{HBDH}$ were on the third day.

Mean peak values of CPK and GOT differed considerably not only between the three groups, but there was also, in the individual patient, a rough 


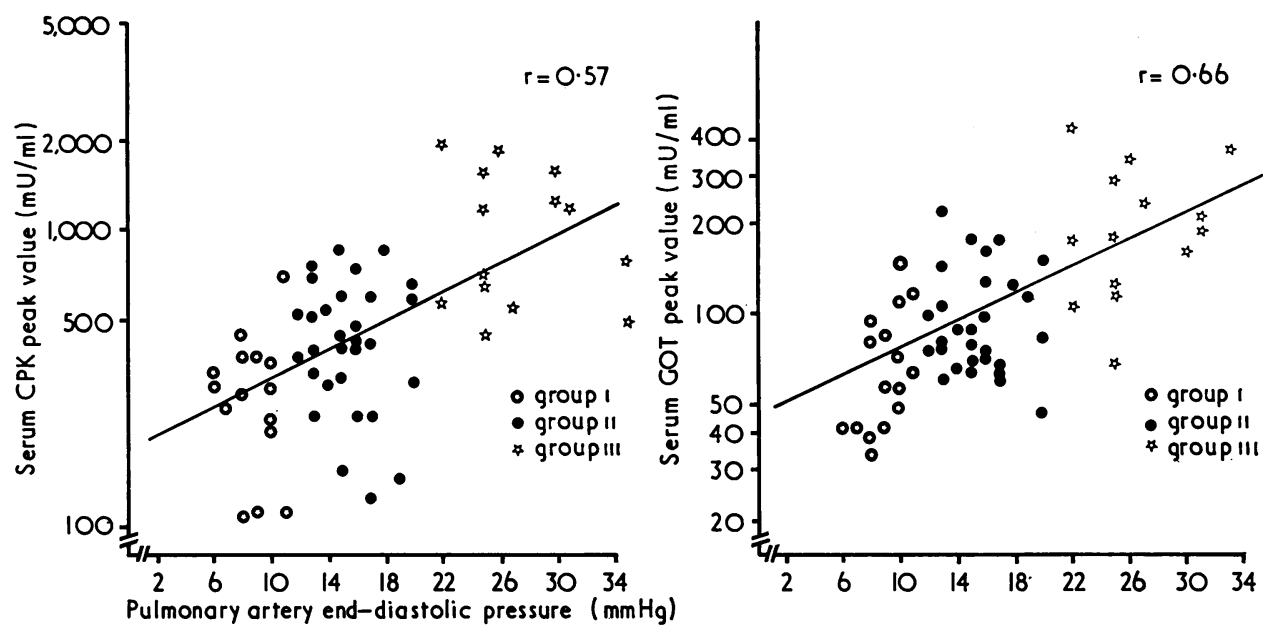

FIG. 3 The maximal serum enzyme concentrations of CPK and GOT are plotted against the pulmonary artery end-diastolic pressure. In the individual patient there is only a rough correlation, as both parameters may be influenced by variables other than infarct size.
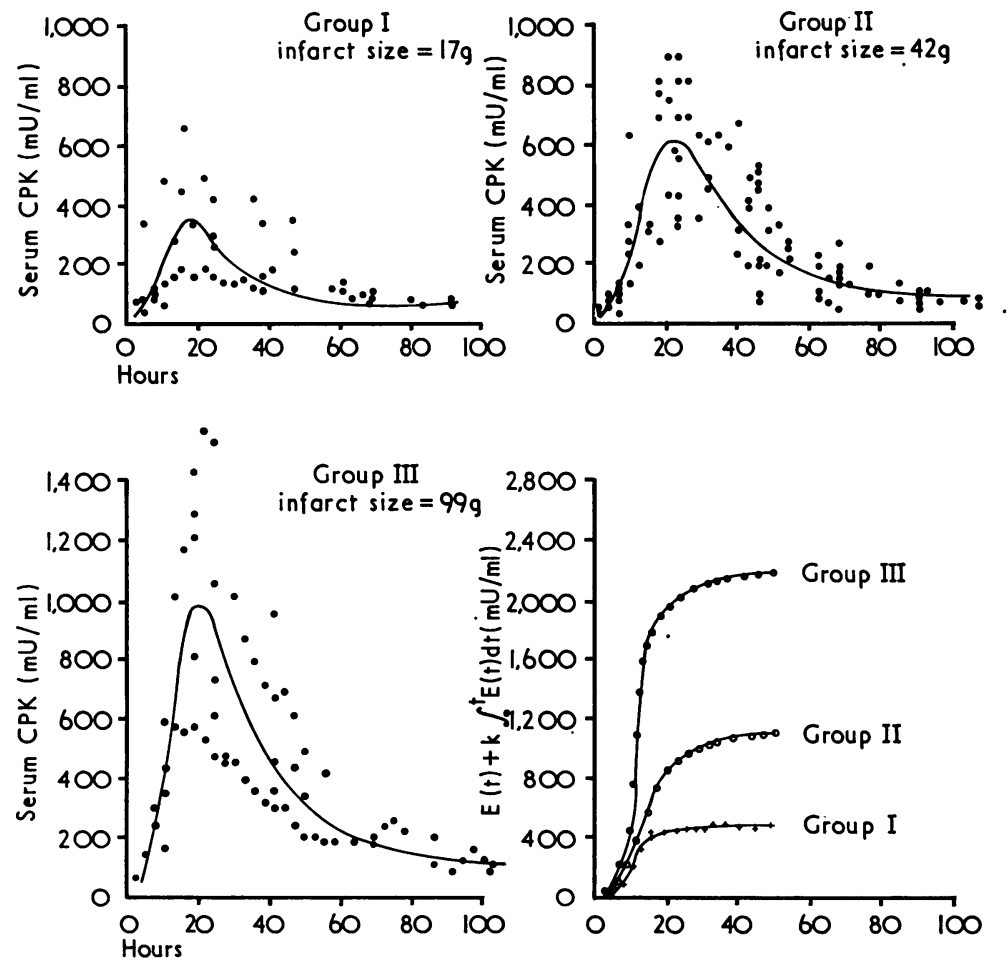

FIG. 4 This figure summarizes the CPK serial values of each group approximated by the mathematically best-fitting curve, which was used for the calculation of the average infarct size of each group. The right lower quadrant shows the CPK invasion curves which differ in their height and rate of rise. 
correlation between pulmonary artery end-diastolic pressure and enzyme rise $(r=0.57$ for $C P K$ and $r=0.66$ for GOT). This is shown in Fig. 3.

CPK serial determinations of each group are shown in Fig. 4. The enzyme values were approximated by the mathematically best-fitting curve. From this curve mean infarct size was calculated according to the equation mentioned above. Mean infarct size in group I was $17 \mathrm{~g}$. In group II the value rose to $42 \mathrm{~g}$. Patients of group III had a mean infarct size of $99 \mathrm{~g}$. As shown in the right lower quadrant of Fig. 4, the maximal amount of CPK that invaded the distribution space increased from group I to III. Besides this there was also an accelerated enzyme invasion with augmenting infarct size, as can be seen from the increasing slope of the invasion curves.

\section{Discussion}

Experimental myocardial infarctions in dogs after coronary artery ligation or coronary embolization revealed that infarct size was related to the rise in serum GOT and LDH (Nydick, Wroblewski, and LaDue, 1955; Lemley-Stone et al., 1955; Ruegsegger et al., 1959). Bang and LaDue (1962) thought that, in man also, serum enzyme activity correlated with the infarct size. They showed that the maximal enzyme rise in patients who survived their infarction was half that of those who died. Kluge (1969) suggested that patients should be divided into a high risk group, with maximal CPK serum values greater than $600 \mathrm{mU} / \mathrm{ml}$, and a low risk group with CPK peak values below $600 \mathrm{mU} / \mathrm{ml}$, as mortality was 50 per cent in those whose CPK values were greater than $600 \mathrm{mU} / \mathrm{ml}$. Recently Chapman and Gray (1973) proposed a prognostic index for acute myocardial infarction, which among other parameters was based on serum GOT increases. In these studies serum enzyme changes were related to clinical data. As clinical signs in acute myocardial infarction may be unreliable, the present study was carried out to compare left ventricular haemodynamic data with serum enzyme changes. Within this context pulmonary artery pressure measured at end-diastole enabled the patients to be divided into three groups, because of the excellent correlation of this with left ventricular end-diastolic pressure $(r=0.93)$ (Merx et al., I973) and the safety of the procedure involved in measuring it. (Swan et al., 1970; Bleifeld, 1973.)

Although none of the enzymes studied specifically has its origin in cardiac muscle, it can be assumed from the uniform behaviour of all enzymes that the increase after myocardial infarction has to be attributed to myocardial damage. Only in the case of the high concentration of GOT in group III may an additional source, probably the liver, be supposed. The haemodynamic impairment of left ventricular function correlated well with the average maximum serum enzyme activity. As peak values of enzyme rise may be affected not only by the infarct size but also by some other variables, such as the rate of biliary and renal excretion, the presence of plasma activators or inhibitors, maximal serum enzyme concentration may not necessarily be an index of infarct size (Cohen and Morgan, 1973). These variables can be neglected, if the infarct size is calculated from the amount of enzyme released into the distribution space.

In group I serial measurements of CPK revealed a mean myocardial necrosis of $17 \mathrm{~g}$ which was significantly less than in groups II and III. These patients had a normal left ventricular end-diastolic pressure, a normal stroke work index $(6 \mathrm{I} \pm \mathrm{I} 5 \mathrm{~g}$ $\left.\mathrm{m} / \mathrm{m}^{2}\right)$, and a normal cardiac index $(2.7 \pm 0.31 . / \mathrm{min}$ per $\mathrm{m}^{2}$ ). No clinical signs of left ventricular failure were observed. With the exception of one patient, who died from acute cardiac rupture, all patients survived.

About 50 per cent of all patients studied belonged

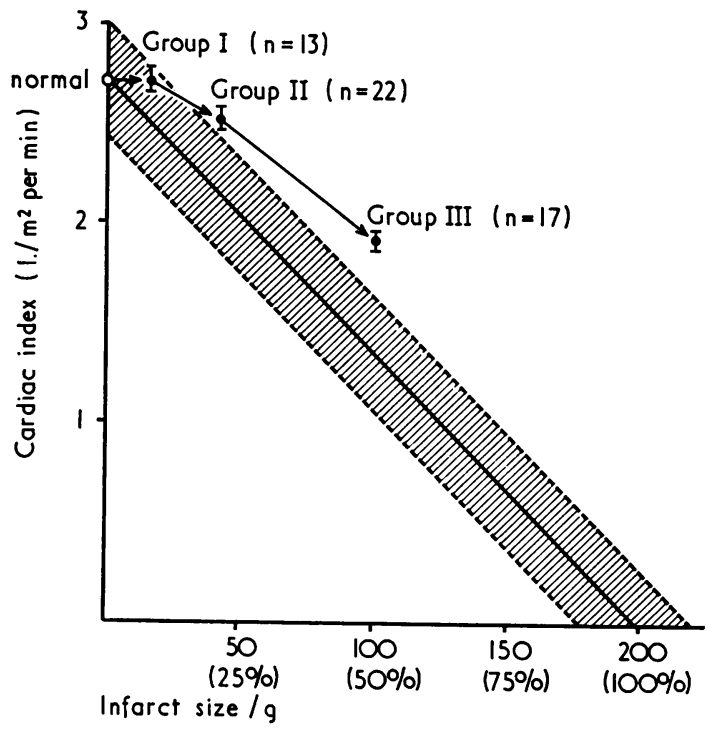

FIG. 5 This figure illustrates the relation between cardiac index and infarct size. The normal value of cardiac index according to the mean age of the whole patient population was estimated to be $2 \cdot 7 \mathrm{l}$./min per $\mathrm{m}^{2}$ (Guyton, fones, and Coleman, 1973) and an average left ventricular weight of $200 \mathrm{~g}$ was assumed (Harnarayen et al., 1970). Cardiac index decreased with increasing infarct size but remained above the theoretically expected reduction. 


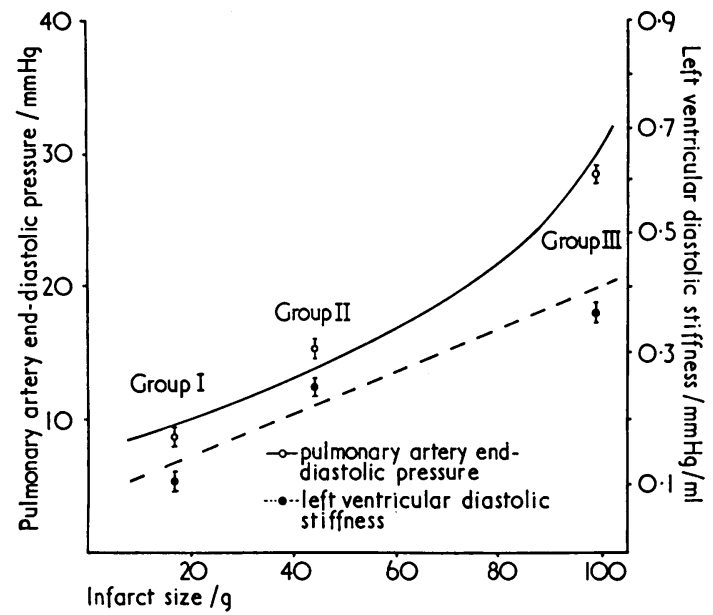

FIG. 6 Left ventricular diastolic stiffness is probably directly related to the infarct size. With increasing infarct size and diastolic stiffness pulmonary artery end-diastolic pressure is likewise raised.

to group II. Their average loss of myocardium was $42 \mathrm{~g}$. Left ventricular filling pressure ranged between 12 and $20 \mathrm{mmHg}$ with a mean of $16.3 \pm 0.4$ $\mathrm{mmHg}$. In contrast to this increase in the enddiastolic pressure in the left ventricle there was no corresponding decline in stroke work index and cardiac index, indicating the involvement of some compensatory mechanisms.

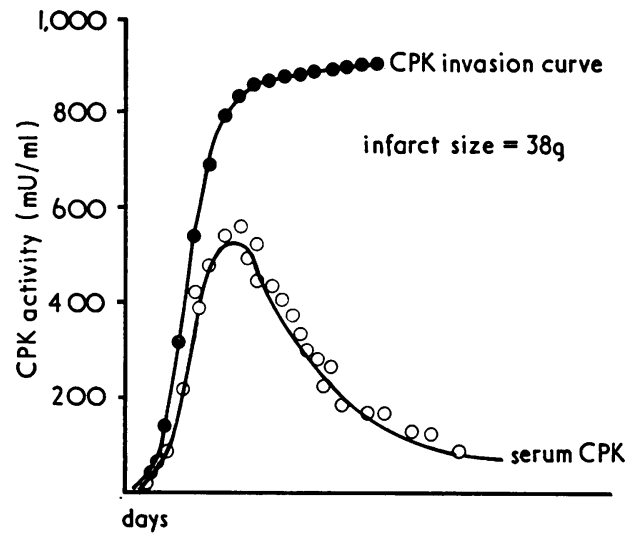

The largest infarcts as estimated from the CPK concentrations with an average of $99 \mathrm{~g}$ were observed in group III with pulmonary artery enddiastolic pressures $>20 \mathrm{mmHg}$. Stroke work index $\left(27.5 \pm 5.7 \mathrm{~g} \mathrm{~m} / \mathrm{m}^{2}\right)$ and cardiac index $(\mathrm{I} .9 \pm 0.2$ 1./min per $\mathrm{m}^{2}$ ) were significantly reduced compared to groups I and II. Complicated infarctions belonged to this group and 87 per cent of patients with cardiogenic shock were in group III.

The clear-cut difference in enzyme rise between the 3 groups demonstrates that on a statistical mean the degree of impaired cardiac function is primarily based on the amount of recent myocardial necrosis. This loss of contractile mass may be expected to result in a reduction of cardiac index directly related to the size of the infarct, if there were no compensatory mechanisms and the infarct area were completely stiff (Swan et al., 1972). Fig. 5 shows, that, in fact, the cardiac index declined with increasing infarct size. However, in all 3 groups the cardiac index remained above the theoretical decrease which would have been expected with infarction of 9,21 , and 50 per cent of the left ventricle. From the compensatory mechanisms which affect cardiac index, heart rate and afterload can be excluded, because in the groups under discussion no change from normal was observed. Several studies in animals (Hood et al., 1970) and estimation of left ventricular volume by ultrasound in humans (Broder and Cohn, 1972) have shown that there is no essential increase of

FIG. 7 The CPK serial values and the CPK invasion curve in a patient with an acute inferior wall infarction of $38 \mathrm{~g}$ are shown in the left part of Fig. 7. At the time of admission his cardiac index was $\mathrm{I} \cdot 9 \mathrm{l}$ l./min per $\mathrm{m}^{2}$ amd his pulmonary artery end-diastolic pressure was $28 \mathrm{mmHg}$ (right part of Fig. 7). The patient died on the 3rd day in cardiogenic shock. The discrepancy between the relatively small infarct size and the severe haemodynamic changes was explained by an old anterior wall aneurysm in addition to the acute myocardial infarction. 
left ventricular end-diastolic volume immediately after myocardial infarction. Accordingly, the relative maintenance of cardiac index above the theoretical reduction seems not to be due to the Starling mechanism. The behaviour of the cardiac index as illustrated in Fig. 5 may be explained by two mechanisms. First, the stiffening of the infarct area results in an increase of stroke volume and cardiac output as compared to a more compliant infarction, since the contraction of the non-infarcted myocardium can only lead to an optimal pressure buildup, when a stiff infarction area serves as a firm resistance. Secondly, contractility of the non-infarcted myocardium was not diminished, but rather was increased. Even in patients of group III with an average infarct weight of $99 \mathrm{~g}(50 \%$ of the left ventricle) the non-infarcted myocardium does not fail to compensate. In considering these points it should be noted that the haemodynamic data were obtained at the time of admission and that in the course of the illness haemodynamic values, especially those of group III, often worsened considerably.

As mentioned above, the elastic properties of the infarct area play an important role in cardiac performance. Previous studies from our laboratory indicated a fourfold increase of mean left ventricular diastolic stiffness after infarction (Bleifield et al., 1974a,b), caused by a regional increase of wall stiffness restricted to the infarct area and not affecting the viable myocardium. Therefore the increase of stiffness after infarction should be dependent on the extent of myocardial necrosis. Fig. 6 shows that mean diastolic left ventricular stiffness is probably linearly correlated to the infarct size. Left ventricular filling pressure is raised likewise. At present, it is only speculation as to whether the rise in left ventricular end-diastolic pressure in the early phase of acute myocardial infarction is exclusively due to the stiffening of the infarct area or whether it may in addition be affected by an increase in left ventricular end-diastolic volume. In the animal experiments of Hood et al. (1970) left ventricular filling pressure increased after coronary artery ligation in the presence of an unaltered left ventricular end-diastolic volume. Recent studies from Broder and Cohn (1972) in the acute phase of human myocardial infarction showed no change in end-diastolic volume in the left ventricle compared to normal as calculated from echocardiograms. The increased left ventricular filling pressure seems to be mainly caused by changes in the wall stiffness.

Another aspect of our study is the possibility of separating the consequences of the recent necrosis from previous changes. The actual haemodynamic alterations measured in an individual patient are the combined result of old and recent loss of myocardium, whereas serial enzyme changes only reflect the amount of recent necrosis. This is shown in Fig. 7, which summarizes the haemodynamic and CPK serial values of a patient with acute inferior wall infarction who died on the 3rd day in cardiogenic shock. At the time of admission pulmonary artery end-diastolic pressure was $28 \mathrm{mmHg}$ and the cardiac index was $\mathrm{I} \cdot 9 \mathrm{l} . / \mathrm{min}$ per $\mathrm{m}^{2}$, indicating the poor prognosis. However, infarct size was only $38 \mathrm{~g}$, which is usually too small to cause cardiogenic shock. Besides the relatively small acute inferior wall infarction necropsy revealed a $5 \times 7 \mathrm{~cm}$ old aneurysm of the anterior wall. The case illustrates that serial determinations of CPK and haemodynamic studies can be combined to separate old from recent myocardial changes.

In conclusion then, it can be stated that haemodynamic and serial enzyme evaluations give useful information for assessing the immediate and longterm prognosis.

The authors acknowledge the assistance of Mrs. $\mathrm{E}$. Halfmann, Mrs. A. Schmitz, Mrs. B. Kraft, and Mrs. K. Lung, of Mr. P. Mayiopulos (Computer Center of the RWTH Aachen), and of Dr. H. M. von Hattingberg (Kinderklinik der Universität Giessen) for his valuable assistance in the pharmacokinetics.

\section{References}

Bang, N. U., and LaDue, J. S. (1962). Comparison of the serum glutamic oxalacetic transaminase, serum glutamic pyruvic transaminase and lactic dehydrogenase activity following acute myocardial infarction. Diseases of the Chest, 41, 384 .

Bleifeld, W. (1973). Bettseitige Kathetertechniken. Intensivmedizin, 10, 232.

Bleifeld, W., Hanrath, P., Merx, W., Heinrich, K. W., and Effert, S. (1972). Akuter Myokardinfarkt. I. Hämodynamik des linken Ventrikels. Deutsche medizinische Wochenschrift, 97, 1807 .

Bleifeld, W., Mathey, D., Hanrath, P., and Effert, S. (1973). Akuter Myokardinfarkt. VII. Prognostische Bedeutung eines neuen Schockindex. Deutsche medizinische Wochenschrift, 98, 1355 .

Bleifeld, W., Mathey, D., Hanrath, P., and Effert, S. (1974a). Acute myocardial infarction. VI. Serial studies of left ventricular wall stiffness and its clinical significance. Basic Research in Cardiology. In the press.

Bleifeld, W., Merx, W., Hanrath, P., and Effert, S. (1974b). Erfahrungen mit dem Swan-Ganz-Ballonkatheter. In 7 th European Federation Congress, Hamburg 1971. In the press.

Broder, M. I., and Cohn, J. N. (1972). Evolution of abnormalities in left ventricular function after acute myocardial infarction. Circulation, 46, 73I.

Chapman, B. L., and Gray, C. H. (1973). Prognostic index for myocardial infarction treated in a coronary care unit. British Heart fournal, 35, 135.

Cohen, L., and Morgan, J. (1973). The enzymatic and immunologic detection of myocardial injury. Medical Clinics
of North America, 57, 105. 
Diamond, G., and Forrester, J. S. (1972). Effect of coronary artery disease and acute myocardial infarction on left ventricular compliance in man. Circulation, 45, I I.

Gladtke, E., and Hattingberg, H. M. (1973). Pharmakokinetik. Springer Verlag, Berlin, Heidelberg, and New York.

Guyton, A. C., Jones, C. E., and Coleman, T. G. (1973). Circulatory Physiology: Cardiac Output and its Regulation, 2nd ed. W. B. Saunders, Philadelphia, London, and Toronto.

Harnarayan, C., Bennett, M. A., Pentecost, B. L., and Brewer, D. B. (1970). Quantitative study of infarcted myocardium in cardiogenic shock. British Heart fournal, 32, 728.

Hood, W. B., Bianco, J. A., Kumar, R., and Whiting, R. B. (1970). Experimental myocardial infarction. IV. Reduction of left ventricular compliance in the healing phase. fournal of Clinical Investigation, 49, 1316.

Hunt, D. U., Pombo Ramos, J. F., Potanin, C., Russell, R. O., Jr., and Rackley, C. E. (1970). Intravascular monitoring in acute myocardial infarction (abstract). American fournal of Cardiology, 25, 104.

Kaltman, A. J., Herbert, W. H., Conroy, R. J., and Kossmann, C. E. (1966). Gradient in pressure across the pulmonary vascular bed during diastole. Circulation, 34, 377.

Kluge, W. F. (1969). Prognostic value of serum creatine phosphokinase levels in myocardial infarction. Northwest Medicine, 68, 847.

Lemley-Stone, J., Merrill, J. M., Grace, J. T., and Meneely, G. R. (1955). Transaminase in experimental myocardial infarction. American fournal of Physiology, 183, 555.

Mayiopulos, P., Mathey, D., Hanrath, P., and Bleifeld, W. (1974). Computer program for the evaluation of the infarct size from CPK serial determinations. Biomedical Engineering. In the press.

Merx, W., Bleifeld, W., Hanrath, P., and Heinrich, K. W. (1973). Akuter Myokardinfarkt. IV. Beziehung zwischen linksventrikulärem Füllungsdruck und enddiastolischem Pulmonalarteriendruck. Zeitschrift für Kreislaufforschung, 62, 835 .

Nydick, I., Wroblewski, F., and LaDue, J. S. (I955). Evidence for increased serum glutamic oxalacetic transam- inase (SGOT) activity following graded myocardial infarcts in dogs. Circulation, 12, 16r.

Page, D. L., Caulfield, J. B., Kastor, J. A., DeSanctis, R. W., and Sanders, C. A. (I97I). Myocardial changes associated with cardiogenic shock. New England fournal of Medicine, 285, 133.

Ruegsegger, P., Nydick, I., Freiman, A., and LaDue, J. S. (1959). Serum activity patterns of glutamic oxalacetic transaminase, glutamic pyruvic transaminase and lactic dehydrogenase following graded myocardial infarction in dogs. Circulation Research, 7, 4 .

Rutherford, B. D., McCann, W. D., and O'Donovan, T. P. B. (1971). The value of monitoring pulmonary artery pressure for early detection of left ventricular failure following myocardial infarction. Circulation, 43, 655 .

Scheinmann, M., Evans, G. Th., Weiss, A., and Rapaport, E. (1973). Relationship between pulmonary artery enddiastolic pressure and left ventricular filling pressure in patients in shock. Circulation, 47, 317.

Sobel, B. E., Bresnahan, G. F., Shell, W. E., and Yoder, R. D. (1972). Estimation of infarct size in man and its relation to prognosis. Circulation, 46, 640 .

Swan, H. J. C., Forrester, J. S., Diamond, G., Chatterjee, D., and Parmley, W. W. (I972). Hemodynamic spectrum of myocardial infarction and cardiogenic shock. A conceptual model. Circulation, 45, 1097.

Swan, H. J. C., Ganz, W., Forrester, J., Marcus, H., Diamond, G., and Chonette, D. (1970). Catheterization of the heart in man with use of a flow-directed balloon-tipped catheter. New England fournal of Medicine, 283, 447.

Williams, J. C. P., O'Donovan, T. P. B., and Wood, E. H. (1966). A method for the calculation of areas under indicator-dilution curves. Fournal of Applied Physiology, 2I, 695 .

Requests for reprints to Professor W. Bleifeld, Abteilung Innere Medizin I/RWTH Aachen, Goethestrasse 27/29, D-5 100 Aachen, West Germany. 